\title{
Experimental Studies on the Influence of Parotin on Metabolism
}

\author{
By
}

\section{Kyoichi YUASA}

(Director, Prof. Shigeo Okinaka, Tokyo University, School of Medicine)

It is reported that Parotin caused a fall of serum calcium, total protein, non-protein nitrogen and amino- $\mathrm{N}$ in normal rabbits, an increase in $\mathrm{A}: \mathrm{G}$ ratio of them and a decrease in urinary nitrogen in normal rats (Takaoka and Yamaguchi). An accerelation of $\mathrm{G}^{14}$-glycine incorporation into rat liver protein and turn over rate of P32-RNA in the rat liver after the administration of Parotin was observed (Ishikawa). On this basis Takaoka has presumed that Parotin may take a part in protein metabolism in animals.

This paper is presenting the results of the investigation designed to make clear the influence of Parotin on metabolism, especially on activities of several enzymes and oxydative phosphorylation in rats.

Following results are obtained:

1) An administration of Parotin produced an increase in the activities of liver cathepsine and glutamic-oxalacetic transaminase of the liver and the heart, whereas it caused a decrease in the activity of liver arginase. A decrease in the activity of serum alkaline phosphatase was noted in rabbits, while no change in liver alkaline phosphatase in rats was recognized after the injection of Parotin.

2) We have previously reported that the administration of Parotin accerelates the oxygen consumption by TCA cycle in the rat liver homogenates. As far oxydative phosphorylation is concerned, $\mathrm{P}: \mathrm{O}$ ratio in the rat liver homogenates given Parotin in advance is demonstrated to be higher than that observed in control rats.

From the results mentioned above, a probable relation of Parotin with the growth hormone in regards with their enzymic actions was discussed in detail, because both of them play important roles in protein metabolism. Considering the protein accumulating and growth promoting actions of Parotin previously reported, the results of this experiment strongly suggest that Parotin may have a hormonal influence on process of protein metabolism. Furthermore, a possible working mechanism and indications of its clinical application of Parotin were discussed in this paper from the stadpoint of physiological actions of adenosine-triphosphosphate.

\section{A case report: Diabetes insipidus with Pubertas praecox \& Hemiplegia dextra due to Ependymoma}

\section{Yoshimi MURAKAMI}

\author{
Second Department of Internal Medicine (Director: Prof. G. KUSUNOKI), \\ Faculty of Medicine, Kyushu University.
}

A 12 year old male.

Clinical findings: Urinary 17-Ketosteroid excretion 12.2 19.6 mg/day. Thorn's test positive, BMR (-) $13 \%$. Glucose torelance increased. Relative lymphocytosis \& eosinophilia. Urinary output 6 12 l/day. Serum ADS (+) 4.9 (Lloyd). TRR 87.2\%. No urinary retention by intravenous injection of hypertonic saline solution \& nicotine. 


\section{パロチンの新陳代謝に及ぼす影響}

\section{（Ｉ）パロチンの諸酵素に及ぼす影響}

東京大学沖中内科

湯 浅 恭 一

緒言

高岡12)山口 (3) はパロチン注射が，健康家鬼の血清カルシウム，総蛋白，残余窒素及びアミノ酸窒素を減少 し，蛋白商（A/G 比）を增加させ，健常白鼠の尿中窒素排泄を抑制すると報告し，之等の事からパロチン は蛋白代謝に関与するのではないかと提唱した．次いで高岡，石川(4) は同位元素 $\mathrm{C}^{14}$ グリシン及びP32を用 いてパロチンがC14ーグリシンの肝蛋白への取り入れを促進し，肝のリボ核酸の Turnover（代謝回転）を促

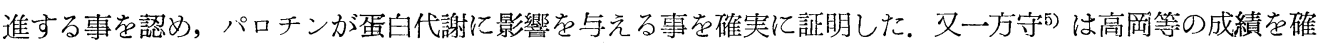
認し，田坂等(6)は家鬼及び老人に於いてパロチン投与が体蛋白の排泄を防ぐと報告，佐々木等》 はパロチン 適量投与が幼弱白鼠の発育を促進する事を認め，角尾8) は鷄胎児のカルシウム沈着促進を報告する等，いず れも高岡等の提唱を裏書するような成績が得られている.

今日迄蛋白代謝に関与するホルモンとして知られているのは, 脳下垂体前葉の成長ホルモンを始めとして, 副腎皮質ホルモン，男性ホルモン，インシュリン等が挙げられる. 就中成長ホルモンは蛋白代謝に関して(1) 窒素蓄積作用 (尿中窒素排泄の抑制)，(2)血中ア之ノ酸窒素低下作用，(3)蛋白同化作用等が知られて居り ${ }^{9)}$, 之等の作用が上述したパロチンの作用とよく一致している事は極めて興味深い. 然るに成長ホルモンの䣼素 系住する作用は(1)白鼠の血漿アルカリフォスファターゼを堌加させるが，正常白鼠の酸フオスファターゼ には影響を与えず，(2)肝カタラーゼを減少させ，(3)成熟雄性白鼠の肝アルギナーゼを減少させるのである10). (4)肝及び腎の $\alpha$ アミノ酸酸化酵素, 筋及び腎の琥珦酸脱水素酔素には特異的変化を与えず, (5) Beaton 等に よれば肝のトランスサミナーゼの中，アラニンーグルタミックトランスアミナーゼは成熟雄性白鼠では減少 し, 幼弱雄性白鼠では増加するが, アスパルチック，トランスアミナーゼには変化を与えない，又 Bartlett 及び Glynn によれば11)，成長ホルモンは in vitro では下垂体剔出白鼠の肝及び腎トランスアミナーゼに影 響を与えないが，in vivo では肝トランスアミナーゼを増加させると述べている。 (6) Mathies ${ }^{12)}$ 等によれば 成長ホルモンは正常白鼠の肝カテプシンを增加させると報告して居り，Gaebler 及び Mathies ${ }^{13)}$ は蛋白代謝 に影響を与える酵素系と成長ホルモンとの関聯について詳述しているが，パロチンの之等素系に対する影響 を検討する事は, 成長ホルモンと対比して極めて興味深いものと考えられるので, 以下の実験を行つた。

\section{実 験 方 法}

体重 $100 \mathrm{~g}$ 前後の雄性白鼠及び体重 $2 \mathrm{~kg}$ 前後の雄性家鬼を15時間絶食とし，パロチンの注射は所定の方法 に従い体重毎皌 $3 \mathrm{mg}$ を腹腔内に投与した，同時に対照群にはパロチンの溶媒で市る $0.6 \%$ 生理的食塩水を同 量注射した，注射後所定の時間に断頭屠殺し，直ちに腹腔を開き，肝，心，脳を取り出す．次いでその必要 量に生理的食塩水又は pH7.4の燐酸バッファーを加え, Potter-Elvehjem の Homogenizer によりホモジェ ネートを作り，アルカリフォスファターゼは Brock 氏法変法 ${ }^{14)}$ ，アルギナーゼはVan Slyke 及び Archibald 氏法15)，カテプシンは Miller 氏法16)，グルタミック・アスパーチック・トランアミナーゼは Tonhazy 氏法 ${ }^{17)}$ により測定した*． 又血清アルカリフオスファターゼは家鬼を用い，注射前及び後に耳静脈より採血して血

*実験に使用した $\alpha$-ケトグルタル酸は, 米, California Foundation for Chemical Research 製品, アスパ ラギン酸は Merck 製品である 
清を分離し，Bodansky 氏法 ${ }^{18)}$ とらり測定しだ

\section{実 験 成 績}

I．アルカリフォスファターゼ

a) 体重 $2 \mathrm{~kg}$ 前後の家鬼12匹を二分して一群を対照とし，他の一群はパロチン $3 \mathrm{mg} / \mathrm{kg}$ を静注して，前， 注射後 $3 ， 8 ， 24$ 時間に採血した。

結果は第 1 図の如く，注射前，注射後 3 時間，8時間，24時間值が，対照群では夫々，2.23，2.14，2.39， 2.29 と多少の動摇を示すのみであるが，之に反してパロチン注射群では夫々，2.20，2.13，1.87，1.62と注 射後は漸次減少して，24時間で最低に達した。

b) 白鼠54匹を対照群14匹，パロチン注射後 3 時間，6時間，12時間及び24時間群各々10匹に分け，所定 の時間に屠殺し, 朋の $10 \%$ ホモジネートを作り, 之を酳素液として使用した。結果は第 2 図の如く, 対照 群, 注射後 $3 ， 6 ， 12$ 及び24時間群夫々 $17.8 ， 14.6 ， 17.0 １ 8.8 ， 16.1$ であつて, 朋の本酵素には一定の傾 向を認めなかつた。

II.アルギナーゼ

a) 白鼠32匹を対照群 8 匹，3時間，6時間，12時間及び24時間各々 6 匹に分け，その肝ホモシエネート のアルギナーゼ活性を測定した.

第 1 図

家鬼血清アルカリフオスファターゼの推移

\begin{tabular}{c|c|c|c|c|c|c}
\hline & No. & 体重 & 前 & 3 & 8 & 24 時 \\
\hline \multirow{4}{*}{ 対 } & 1 & 1.9 & 4.90 & 4.85 & 5.12 & 4.81 \\
& 2 & 2.1 & 2.57 & 2.63 & 2.42 & 2.26 \\
& 3 & 2.2 & 1.34 & 0.92 & 0.98 & 1.06 \\
照 & 4 & 2.3 & 1.31 & 1.57 & 1.78 & 1.33 \\
& 5 & 2.2 & 2.06 & 1.78 & 1.76 & 2.16 \\
群 & 6 & 2.3 & 1.24 & 1.18 & 1.33 & 1.18 \\
\cline { 2 - 7 } & 平 & 均 & 2.23 & 2.14 & 2.39 & 2.29 \\
\hline ㅇ & 7 & 2.2 & 1.51 & 1.43 & 1.34 & 1.35 \\
チ & 8 & 1.9 & 2.83 & 2.67 & 2.49 & 2.18 \\
チ & 2.0 & 3.08 & 3.37 & 2.13 & 1.86 \\
注 & 10 & 2.0 & 2.88 & 2.58 & 2.48 & 2.31 \\
射 & 11 & 1.8 & 2.06 & 1.76 & 1.91 & 1.58 \\
群 & 12 & 2.0 & 0.86 & 0.95 & 0.86 & 0.66 \\
& 平 & 均 & 2.20 & 2.13 & 1.87 & 1.62 \\
\hline
\end{tabular}

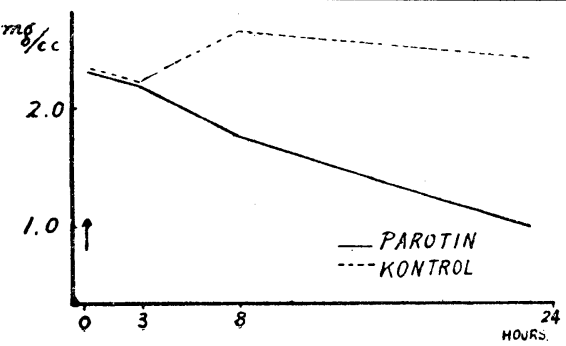

結果は第 3 図の如く，注射前值は平均 110 であ るのに対し，パロチン注射群では，3時䦬， 6 時 間，12時間及び 24 時間群夫々 $103 ， 101 ， 97$ 及び 89 であつて実測值並びに平均值共に減少して，24時 間で最低に達している。

b) 白鼠56匹を対照群 14 匹，3 時間及び 6 時間 群各々15匹，12時間及び24時間群各々 6 匹に分け

第 2 図

ラッテ肝アルカリフオスファターゼの変動

\begin{tabular}{c|c|c|c|c|c}
\hline & 対 照 & 3 & 6 & 12 & 24 時 \\
\hline 匹数 & 14 & 10 & 10 & 10 & 10 \\
\hline 平均 & 17.8 & 14.6 & 17.0 & 18.8 & 16.1 \\
\hline
\end{tabular}

$m g / 8$

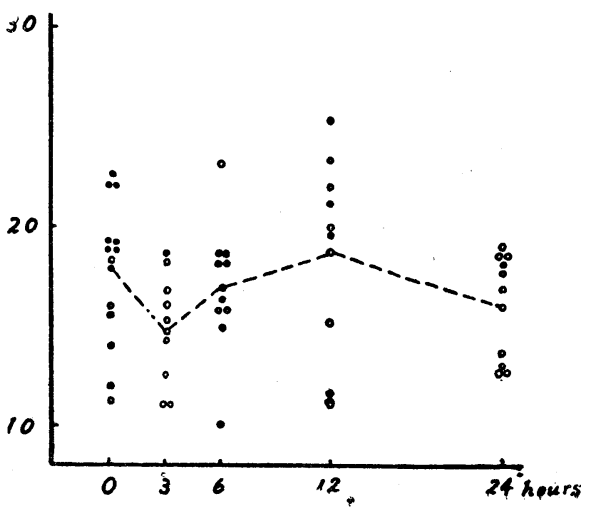


第3図 パロチンの白鼠肝アルギナーゼ に及ぼす影響（空腹群）

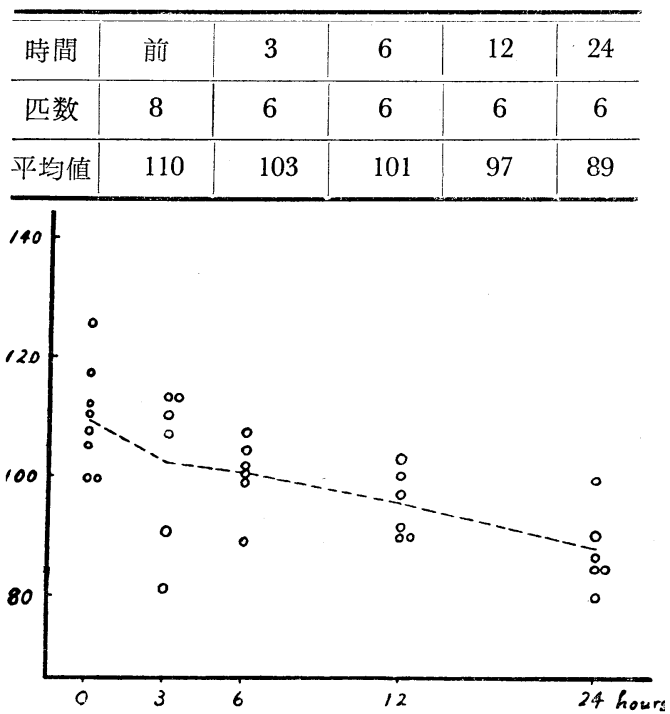

第4図 パロチンの白鼠肝アルギナーゼ に及ぼす影響（食餌給与群）

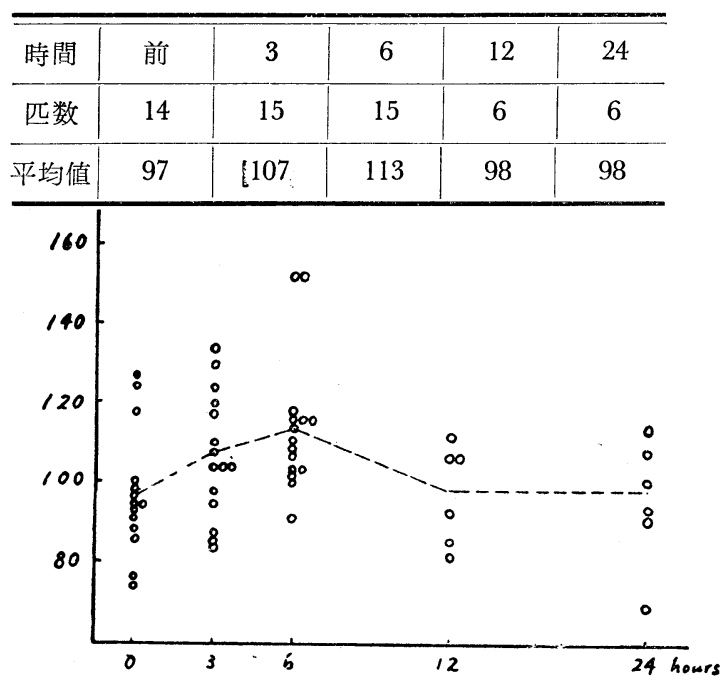

第 5 図 パロチンのカテプシンに及ぼす影響

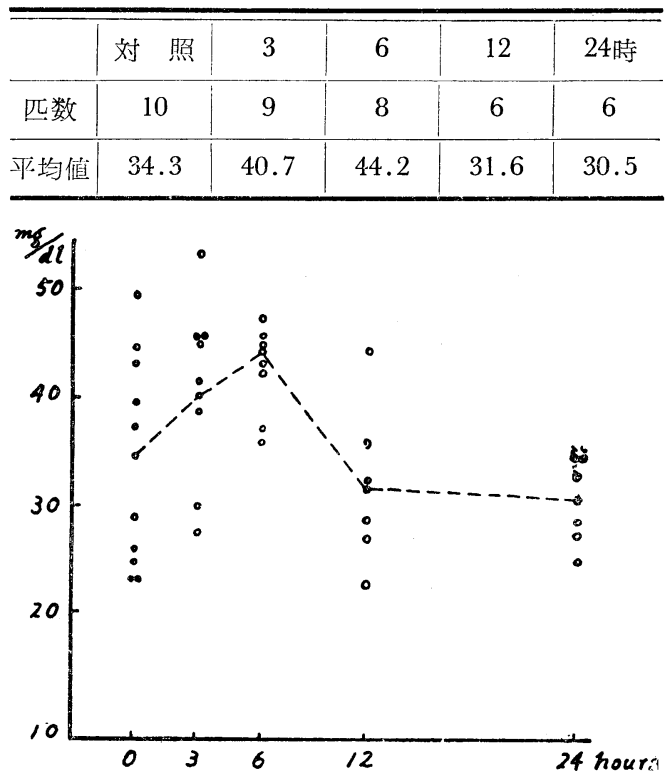

第 6 図 パロチンのトランスアミナーゼ に及ぼす影響（予備実験）

\begin{tabular}{|c|c|c|c|}
\hline \multicolumn{2}{|c|}{ ホモヂエネート $30 \mathrm{mg}$} & \multicolumn{2}{|c|}{$50 \mathrm{mg}$} \\
\hline 対 照 & パロチン & 対 照 & パロチン \\
\hline 5.7 & 7.7 & 14.6 & 15.7 \\
\hline 6.4 & 10.7 & 16.0 & 16.7 \\
\hline $8 . \dot{7}$ & 8.1 & & 16.0 \\
\hline $8 \cdot 0$ & 6.9 & & \\
\hline 7.8 & 8.2 & 15.3 & 16.1 \\
\hline
\end{tabular}

いづれも絶食を行わずに，その肝アルギナ 一ゼ活性を測定した。

この場合は第 4 図の如く，注射前值は平 均97であるが， 3 時間及び 6 時間群の值は 夫々 107 及び113と一時上昇し，12万至 24 時 間群ではいづれも98と，略々注射前值に戻 つている. .之は Lightbody 及び Kleinman の報告 ${ }^{19)} の$ 如く, 蛋白食投与が肝アルギナ゙ーゼ活性を增加させ たものと考えられる。

III.カテプシン

白鼠39匹を対照群10匹，3 時間群 9 匹，6 時間群 8 匹，12時間及び24時間群各々6 匹に分け，その肝ホモ ジェネートのカテプシン活性を測定した。

結果は第 5 図の如く対照群平均值は34.3であるが， 3 時間及び 6 時間群では夫々 $40.7,44.2$ とテプシン 活性が増加し，12時間及び24時間群では夫々31.6，30.5と略々対照群の值に戻つている， 
第 7 図

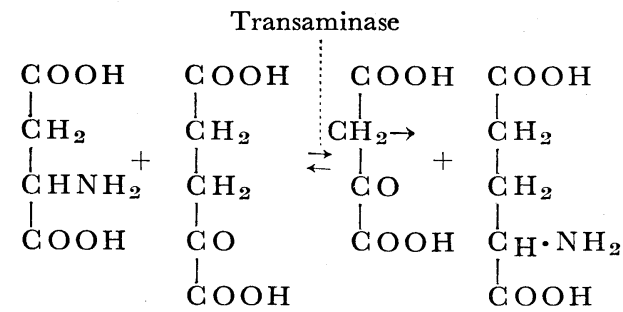

Aspartic $\alpha$-Ketoglutaric oxaloac- Glutamic acid acid
IV. トランスアミナーゼ

トランスアミナーゼは Needham がその存 在を示唆20)して以来, Szent-Györgyi 等が多く の研究業績を発表している䣼素であつて， $\alpha$-ア 々ノ酸のア之ノ基を $\alpha$-ケト酸へ転移させる作用 を有する。生体内にはアスパーチック・グルタ ミックトランスアミナーゼとアラニン・グルタ ミックラトンスアミナーゼとがあり前者の含量 が遙かに多い，白鼠では心筋，骨格筋，脳，朋 臓，婜藏，等丸の順に存在するといわれている ので，本実験に於いては，心及び肝についてア スパーチック・グルタミックトランスアミナー ゼのみを測定した。

a）本実験を行うに先立つてアスパーチック ・グルタミツクトランスアミナーゼ活性を,

(Warburg gasmetry) ${ }_{\mathrm{COOH}}$

Pyruvic acid

(Colorimetry)

第 8 図 パロチンのトランスアミナーゼ に及ぼす影響

\begin{tabular}{c|cc|c|c}
\hline & & & \multicolumn{1}{c}{ Qt } & 匹 数 \\
\hline \multirow{4}{*}{ 肝 } & 対 照 群 & $95 \pm 7$ & 15 \\
& 3 & 時 & $118 \pm 4$ & 16 \\
& 6 & 時 & $102 \pm 8$ & 21 \\
\hline \multirow{4}{*}{ 心 } & 対 & 照 群 & $112 \pm 6$ & 12 \\
& 3 & 時 & $132 \pm 4$ & 17 \\
& 6 & 時 & $124 \pm 4$ & 22 \\
\hline
\end{tabular}

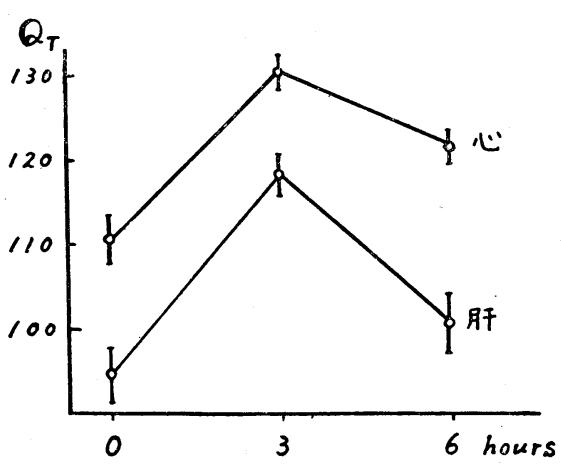

Ames 及び Elvehjem のワールブルグ検压計に

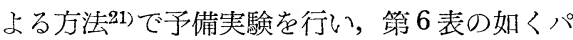
ロチン注射後 3 時間群が対照群に比し，高い活 性を示す傾向を得たが，乙の方法では一時に多 数の試料を測定し得ないので，以後は Tonhazy の方法 ${ }^{17)}$ 亿従つた。即ち第 7 図に示す如く Lアスパラギン酸と $\alpha^{-}$ケトグルタル酸を基質と してトランスアミナーゼを作用させると，オキ ザロ醋酸と L-グルタミン酸になる。ワールブ ルグ検圧計を使用する方法は，生成したオキザ ロ醋酸にアニリンチトラートを加えて炭酸ガス と焦性葡萄酸に分解し，その炭酸ガス量を測定 する方法であり，Tonhazy の方法は焦性葡萄酸 を 2,4 ヂニトロフェニルヒドラヂンによつて 発色せしめ，之を標準曲線と比較して比色定量 する方法である。トランスアミナーゼ活性虫之 よりQT（藏器乾燥重量当り，単位時間内の炭 酸ガス発生モル数）を計算して表わした。

b) 白鼠54匹を対照群15匹，3時間群，17匹 6 時間群，22匹に分け，その肝及び心を $\mathrm{pH} 7.4$ の燐酸バッファーで $1 \%$ ホモジェネートとして， 各々のトランスアミナーゼ活性を測定した。

結果は第 8 図の如く, 肝圜では対照群平均值 が95であるのに，注射㷋 3 時間及び 6 時間群で

は夫々，118，102 と上昇を示し，心蔵に於いても対照群平均 112 亿対し，3時間及び 6 時間群平均值は夫々 132，124 と上昇を示している．他の酵素活性が，いづれもパロチン注射後 6 時間或いは24時間で最高となつ ているのに比し，3時間值が最高值を示しているのは興味深い所見である. 


\section{考察}

アルカリフオスファターゼは燐酸分解に重要な醭素であり, 骨を始めとして広く体内各臟器, 分泌液中に 存在し，その生理作用は不明の点も少くないが，化骨，粲細尿管，小腸等の糖吸収に関与し，最近は又蛋白 合成作用に何等かの関係を有するものと云われている。田中は 3 例の泰跹性進行性筋菱縮にパロチンを使用 して本醉素の増加する事を報じ22)，伊藤は家鬼に 1 力月連続注射を行い逆に低下するとし，一定の傾向が得 られていない. 本報告に於いては血清のアルカリフオスファターゼは 1 回注射により低下する事を示してい るが，肝蔵の酔素活性には変化が認められなかつた。成長ホルモンが血槳アルカリフオスファターゼを増加 するという報告10), 或いはテストステロン, アンドロステロンにより去勢白鼠の肝アルカリフオスファター ゼが変化しないとい5報告23) と考え合せ今後更に検討を要するものと思う。

アルギナーゼは Krebs-Hensleit のオルニチン・サイクルに関与する醉素であつて，アルギニンを分解し オルニチンと尿素にするもので, 動物の肝細胞核に多く存在し, 蛋白代謝に於いて異化作用が強い時に活性 が高く，発育の盛んな組織では減少するとされている，又蛋白異化的に作用するコルチゾン36)を注射する事 により，アルギナーゼが增加するとの報告がある37)本実験に於いても空腹白鼠のアルギナーゼはパロチン注 射により減少し，アルギニンの分解が抑制されるととがうかがわれ，蛋白代謝は異化よりも同化の方に動い ている事を示唆している. 又食事を充分に与えた II b) 実験に於いてはアルギナーゼ活性が一時増加してい るが, 之は前述の説明で良く理解されるものと思う。ACTHにより肝アルギナーゼが増加し, 成長ホルモ ンが減少させるという報告 ${ }^{24)}$ は，本実験と比へ極めて興味深い．

カテプシンは細胞内に存在する醉素であつて，始め動物の死後自家融解を行う酵素として発見されたるの であるが，今日では生体内にあつてペプチッドの合成並びに分解を行う酵素として重要視されている，本醳 素はＩＩI 四及びNの四種に分類されその意義が追求されている，本実験に於いてはカテプシン I を主目標と して測定し, 成長ホルモンと同様に 6 時間群に増加が見られている事は, パロチンによるペプチッドの合成 並びに分解の速度の増加即ち，代謝促進のある事を予想させるものである.

トランスアミナーゼは Braunstein 及び Kritzmann に上れば 1) グルタミン酸脱水素酵素と共䡉して酸 化的脱アミノ化を行い，2）或る種のアミノ酸を合成するとされ25), Herbst によれば 3) ペプチド基の合成 や，4）尿素の合成にも関与するばかりでなく，その他多くの中間代謝産物にも関係すると言われている23 ので, 他の蛋白代謝に関係する多くのホルモンについても検討が加えられている. 即ち Hayano 及び Dorfman はDOCA* 333r/ccが白鼠肝臟のトランスアミナーゼを抑制すると報じ27)，一方 Dirscherl 等はテストス テロン，テストステロン・プロピオネート，デゾキシコルチコステロン及び DOCA は 50\%/cc in vivo で はいずれもトランスアミナーゼ活性に影響を与えない28)としている. 又 Eischeid 及び Kochakian はコルチ ソンアセテートを毎日 1 週間以上連続投与すると, 肝臓のアスパーチック・グルタミック・トランスアミナ 一ゼは減少するが，心臟及び腎藏のトランスアミナーゼは増加すると云い299, Rindi は白鼠の副婜を摘出す ると心藏, 筋肉及び脳のグルタミック・アスパーチック・トランスアミナーゼは減少するが, 肝蔵のトラン スアミナーゼには認むべき変化がなく，副腎摘出白鼠にコルチソンを与えると，心臟及び脳のトランスアミ ナーゼは正常值に復し, 筋肉及び肝臟のトランスアミナーゼは正常值以上に増加する30) と報告している。乙 の時又 DOCA を与光ると肝藏，心藏及び胹のトランスアミナーゼには影響なく筋肉トランスアミナーゼの みが正常值に復すると言う．正常白鼠にコーチソンのみを投与すると朋トランスアミナーゼ活性のみが高ま り，DOCA にはての作用がないと言う. Awapara 亿よれば去勢は白鼠捸護腺前葉のグルタミック・アラニ ン・トランスアミナーゼ活性を抑制するが，乙の場合テストステロン・プロピオネートを投与すれば，その 活性が回復するという31). Kochakian 等によれば, 成熟白鼠の甲状腺を摘出すると, 肝臟重量当りのトラン スアミナーゼ活性には変化がないが, 朋臟重量の減少に伴つて, トランスアミナーゼの全量は減少するとい

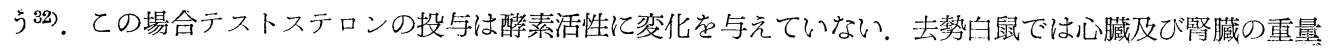

* Desoxycorticosterone Acetate 
が減少し，之に伴つてトランスアミナーゼ全量が減少するが，ての際はテストステロン投与が，減少した醭 素を回復させるという。

パロチン注射後カテプシン, アルギナーゼ，アルカリフオスファターゼ等の他の酥素群が 6 時間でその活 性が最高又は最低となるのに，独りトランスアミナーゼのみが 3 時間で最高の活性を示す理虫については， 生体内の中間代謝の機序は複雑であるから，外部加ら簡単に予断する事は出来ないが，以下推測を試みてみ 上5。高岡, 山口，石川は血清蛋白，残余窒素，アミノ窒素もパロチン注射後 6 時閂で最低となる事を報し ている。一方著者はパロチン注射後白鼠肝ホモジェネートの TCA* 回路の回転が， 3〜6時間目に最も促 進される事を報告し ${ }^{33)}$ て居り，生体はパロチン注射により上記実験成績の如く各種醭素系の活性を增し，之 が更に TCA 回路の回転促進と, 陌素系增加とを順次に起すものと思われる。トランスアミナーゼは之等の 変化に先だつて活性が高まり，血清中の窒素を利用し得る形のアミノ基とし，一方アミノ基を失つた諸有機 物, 或いはア之ノ基転移によつて新たに生じたアミノ酸を, 蛋白合成や, TCA 回起に利用され易くするも のと考えられる。

以上の結果を, 窒素蓄積作用, 成長促進作用がパロチンと同様である成長ホルモンと, 総括比較検討して みると，アルギナーゼについては両者が同様の作用を示すが，カテプシン及びトランスアミナーゼ活性増加 作用はパロチンが強く, 肝アルカリフオスファターゼに対しては, 成長ホルモンは增強しているが, パロチ ンは一定の傾向を示さない，成長ホルモンは肺カタラーゼ活性を減少させるが，教室加藤（博）の実験によ ると ${ }^{34)}$ ，パロチンは之を堌強させるのである . 尚パロチンは心筋トランスアミナーゼ活性をも増強する事は, 最近心筋梗塞症の際血清トランスアミナーゼが増加するという諸家の報告品) と考え合わせて興味ある事実で ある。

一方臨床的応用に当つて成長ホルモンが強い Diabetogenic action を有するに反して, パロチンが全くて の作用を有しない事は，非常に有利な点であると考える。更にパロチンは成長ホルモンが有しないグルタミ ック・アスパーチック・トランスアミナーゼ活性促進作用を有する事は，パロチンが或る方面では成長ホル モンより更に強力な作用を示すものと思われる.

\section{結論}

パロチンの諸酵素系へ及ばす影響について，主として白鼠を用いて実験を行い，パロチンは 1) 血清アル カリフオスファターゼ活性を減弱させる傾向を有するが，肝のそれには影響を認め難く，2）肝アルギナー ゼ活性を減弱させ，3）肝カテプシン活性を増加させ，4）肝及び心トランスアミナーゼ活性を共に堌強し た.

以上の結果を蛋白代謝に関するホルモンである成長ホルモンと比較検討し，パロチンの蛋白蓄積作用及び 成長促進作用と合わせ考えて, パロチンが蛋白合成に関与する事を強く示唆する成績を得た。

擱筆するに当り, 御指導, 御校閲を戴いた恩師沖中教授に深謝すると共に, 終始御指導, 御協力を頂いた 高岡講師を始め, 教室山田, 山口両博士, 石川学士，鈴木康夫氏に厚く感謝する.

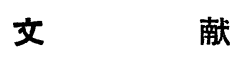

1) Y. Takaoka et al. : Klin. Wschr. 32 (15) : 369, 1954.

2) Y. Takaoka et al. : Ibid. 33 (15) :

156. 3) 山口時三: ホルモンと臨床, 2 巻 4 号, 1022頁, 1954.

4) 石川俊之 : 日本内分泌 学会雑誌 (発表予定)

5) 守一雄他 : ホルモンと臨床, 3 巻 9 号, 1017頁, 1954 .

6) 田坂

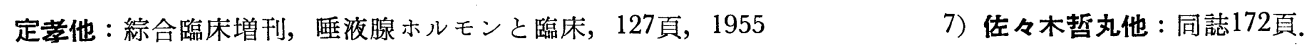

8）角尾：28年度文部省総合研究報告集録（医学及び薬学）倕液腺ホルモンに関する研究，班長緒方知三郎

* Tricarboxylic acid 
P 269 .

9) Recent Progress in Hormone Besearch Vol. III. 1948.

10) Beaton, G.H. : Proc. Soc. Exp. Biol. Med. $83: 781,1953 . \quad 11)$ Bartlett, P.D. \& Glynn, M. : J.B.G. $187: 261,1950$. 12 ) Mathies, J.C., Palm, L. \& Gaebler, O.H. : Endocrinol. $45: 480,1949 . \quad 13)$ Gaebler, O.H. \& Mathies, J.C. : Ibid. $48: 623,1951$. 14) 崎田隆夫 : 日本消化機病学会雑誌, $50(11): 1$ 昭 28 . 15) Van Slyke, D.D. \& hrchibald, R.M. : J.B.C. $165: 293,1946 . \quad 16)$ Miller, L.L. : J.B.C. $152: 603$, 1944. 17) Tonhazy, N.E., White, N.G. \& Umbreit, W.W. : Arch. Biochem. $28: 56,1950 . \quad 18)$ Bodansky, A. : J.B.C. $101: 93,1933 . \quad 19)$ Lightbody, H.D. \& Kleinman, A. : J.B.C. $129: 71,1939$ 20) Needham, D.M. : Biochem. J. $24: 208,1930 . \quad 21)$ Ames, S.R. \& Elvehiem, C.V. : J.B.C. $166: 81$. 22) 田中剛二他：第70回内科学会関東地方会, 昭29年. $\quad 23)$ Kochakian, C.D. \& Stettner, C.E. : Am. J. Physiol. 155 : 255, 1948.24 Fraenkel-Conrat, H., Simpson, M.E. \& Evans, H.M. : J.B.C. 147 : 99 , 1942. 25) Braunstein, A.E. \& Kritzmann, M.G. : Enzymologia $2: 129,1936 . \quad 26)$ Herbst, R.M : Advances in Enzymology $4: 75,1944 . \quad 27)$ Hayano, M. \& Dorfman, R.I. : Ann. N.Y. Acad. Sci. $54: 608,1951 . \quad 28)$ Dirscherl, W. : Biochem. Zschr. $323: 399,1953 . \quad 29)$ Eischeid, A.M. \& Kochakian, C.D. : Proc. Soc. Exp. Biol. Med. 85 : 339, $1954 . \quad 30)$ Rindi, G. : Arch. Sci. Biol. 38 : 155, $1954 . \quad 31)$ Awapara, J. : Endocrinology $51: 75,1952 . \quad 32$ Kochakian, C.D., Reed, B.A. \& Eischeid, A.M. : Am. J. Physiol. $177: 413,1952$.

34) 加藤博 : Zschr. f. ges. exp. Med. $127: 203,1956$.

33）湯浅恭一他 : 内分泌 2 巻 1 号, 10 頁, 昭 30 . 35) Karmen, A., Wroblewski, F. \& Ladue, J.S. : Girculation $11: 871$, 1955. Kattus ir., A.A., Watanabe et al. : J.A.M.A. : 160 (1) : 16, 1956. Cannon, P.R., Frazier, L.E. \& Hughes, R.H. : Arch. Path. 61 (4) : 271, $1956 . \quad$ 37) 小田正幸 : 日本臨床, 14 巻 2 号, 45 頁, 炤 31 . 


\title{
パロチンの新陳代謝に及ぼす影響
}

\author{
（II）パロチンの $\mathrm{P} / \mathrm{O}$ 比に及ぼす影響
}

東京大学冲中内科

湯 浅 恭 一

\begin{abstract}
緒言
パロチンが緒方教授の提唱した骨塩代謝に関与するのみならず，蛋白代謝にも影響を与えると云う高岡の 説は，その後山口，石川333等により証明され，蛋白代謝の中でも特に合成面に働く事が報告された。著者も その一部として，第 1 報に於いてパロチンの諸醳素に及ぼす影㗽を実験し，ての説を肯定する結果を得た。

一方臨床的に高岡, 宇尾野はパロチンを注射された重症筋皿力症息者の血清中エステル型ビタミン $\mathrm{B}_{1}$ が 増加する事を報告したが1)，乙の事実はパロチンがビタミン $\mathrm{B}_{1}$ の燐酸化に (Phosphorylation) 関与する事 を示している，ビタミン $\mathrm{B}_{1}$ がエステル型に変化する為には，ATP*の燐酸基が分離してビタミン $\mathrm{B}_{1}$ に結 合し, ATP 自身は ADP** になると考光られる.

したがつてパロチンの注射がビタミン $\mathrm{B}_{1}$ のエステル型を増加させる事は，パロチンが ATP の代謝に関 与する事を予想させる事実である。 ATP によつて代表される高亲ルギ一燐酸化合物は蛋白合成を含めて

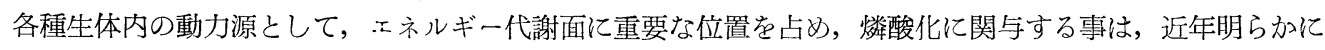
された甚で偽味ある問題である．ATP 自身は溶液の形では極めて不安定であり，合成されると同時に分解 も起つているので, ATP を直接測定する方法は，現在では極めて因難である。従つて著者等はパロチンの TCA 回路に及ぼす影響を研究して，パロチン注射が白鼠肝ホモジェネートの酸素吸収を増加させることか ら，パロチンが ATP を増加させる事を推論した22)．しかし酸素吸収の增加のみから ATP の増加を断定す る事は, 危険な場合もあり得るので, 今回はより直接的にてれを証明する為に, 現在最も信頼し得る方法と されている $\mathrm{P} / \mathrm{O}$ 比を測定した。
\end{abstract}

$\mathrm{P} / \mathrm{O}$ 比とは酸化的燐酸化 Oxidative phosphorylation, 或いは燐酸化に共䡉せる酸化 Oxidation Coupled with Phosphorylation とも言われ，基質が TCA サイクル等によつて酸化すれて，酸素一分子が吸収され

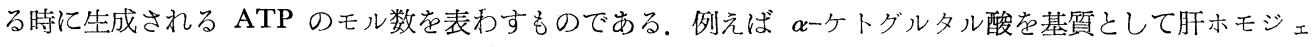
ネートに加えると，之が一分子の酸素を吸収して炭酸ガスと水とに分解する際に，無機燐が吸収され之が ADP と結合して ATP となる. この時吸収される無機燐と，吸収された酸素との比を測定するのである. 同時に生じた ATP はクレアチン或いはブドウ糖十へキソキナーゼによつて，安定なクレアチン燐酸或いは ブドウ楉 6 燐酸に高エネルギー燐酸結合基を与えて ADP となる為, 反応が円滑に進行するのである。（第 1 図参照)．乙の場合 ATP-ADP 系は燐酸基をその受容者へ運ぶ触媒の如く作用する．P/O 比の測定はあ る程度熟練すれば比較的正確且容易に行える方法であり，パロチン注射が $\mathrm{P} / \mathrm{O}$ 比を高める時は，パロチン が生体内で ATP を増産する事になり，パロチンの作用機転を解明するのに有用と考えられるので, パロチ ン注射後の白鼠朋ホモジェネートについて P/O 此の測定を行い, 興味ある結果を得たので報告する.

\section{予 備 実 験}

体重 $100 \mathrm{~g}$ 前後の雄性白鼠 6 匹を選び, 約18時間空腹とし, 之等を 2 群に分けて, 一群にはパロチンの溶 媒である $0.6 \%$ 食塩水を注射して対照とし, 他群にはパロチン体重毎䏕 3 庇を腹腔内に注射し, 両群共注射 後 6 時間で断頭開腹し直に肝藏を取出し，トルジオンバランスで約 $500 \mathrm{mg}$ を科量した。乙の肝蔵を予水

*アデノシン三燐酸 **アデノシン二燐酸 
冷して扔いた Potter-Elvehjem のホモジェナイザーに入れ, 4 容の等張氷冷塩化カリ・燐酸バッファー(10容 の $0.9 \%$ 塩化カリ溶液と 1 容の $\mathrm{M} / 10$ 第二燐酸カリ溶液を混じたもの) を用い, 水冷しつ〉均等化し,この亦 モジェネートを醅素液としてその $\mathrm{P} / \mathrm{O}$ 比を測定した。注射後 6 時間で白鼠を殺したのは先に報告した TCA 回路による酸素吸収が，6時間群に於いて最も高かつた1) からで，基質としては $\alpha$-ケトグルタル酸 (California Foundation for Biochemical Research 製品)を用いた.

$\mathrm{P} / \mathrm{O}$ 比の測定は先ず第 1 表の処方の様に，クレアチンを用いる方法3で行つたが，緒方等によればチトク ローム $\mathrm{C}$ 及び $\mathrm{DPN}^{*}$ の添加は $\mathrm{P} / \mathrm{O}$ 比に影響しないいので，之等を加えずに実験を行つた，各溶液はいずれ も予む $\mathrm{pH}$ を7.4に合わせた。 ワールブルグ検圧計フラスコは一つの試料につき 2 コづつ用い, 気相は空気, 摂氏 30 度で空振り 5 分後後, 一コは直ちに側空内の $5 \%$ 三塩化醋酸を混して反応を中止し, 無機燐を測定, 他の一コは 3 分毎に 6 分間酸素吸収を測定した後, 同様に反応を中止して無機燐を測定しての二者の差加 減少無機燐のモル数を計算した。無機燐の測定は Lowry-Lopez の方法5りより発色せしめ，日立製ベックマ ン型分光光電比色計（波長 $700 \mathrm{~m} \mu$ ）を用いた。

第 1 表

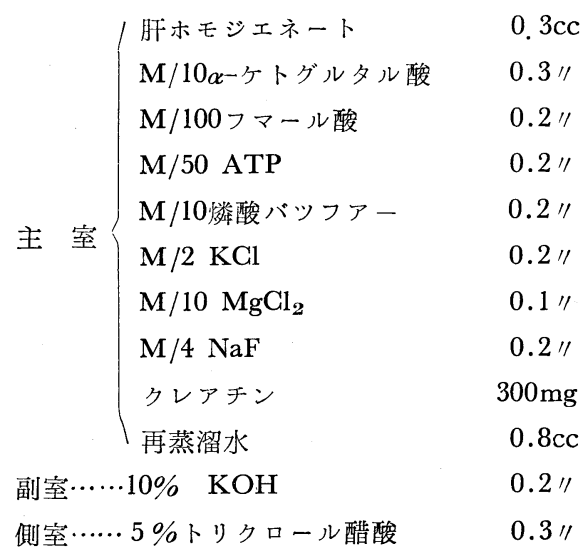

第 2 表

\begin{tabular}{|c|c|c|c|}
\hline & $\begin{array}{c}\text { 酸素吸収 } \\
\mu \text { atoms }\end{array}$ & 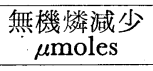 & $\mathrm{P} / \mathrm{O}$ \\
\hline $\begin{array}{c}\text { パロチン群 } \\
\text { No. } 30\end{array}$ & 1.52 & 1.65 & 1.08 \\
\hline No. 33 & 1.95 & 2.00 & 1.03 \\
\hline No. 38 & 1.35 & 1.37 & 0.99 \\
\hline 平均 & 1.61 & 1.67 & 1.05 \\
\hline 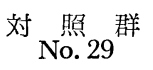 & 1.16 & 0.59 & 0.51 \\
\hline No. 32 & 1.82 & 0.86 & 0.47 \\
\hline No. 51 & 1.32 & 0.68 & 0.52 \\
\hline 平均 & 1.43 & 0.71 & 0.50 \\
\hline
\end{tabular}

結果は第 2 表の如く, パロチン群は平均 1.05 , 対照群は平均 0.50 で, パロチン群の $\mathrm{P} / \mathrm{O}$ 比は対照群の略 々 2 倍の值を示し, 酸素吸収も多い. $\mathrm{P} / \mathrm{O}$ 比が理論值（3３.2) よりも低いのはミトコンドリアを分離せ ずにホモジェネートを用い た為ではないかと思われ

$$
\text { 事一四 }
$$

る. 之でパロチン注射が白 鼠肝藏ホモジェネートの醭 素系による $\mathrm{P} / \mathrm{O}$ 比を高め る見通しを得た。

\section{本 実 驗}

予備実験で生成されるク レアチン燐酸は稍々不安定 であり, 測定の際の実験操 作にも熟練を要するので, 本実験にはより確実で, 反
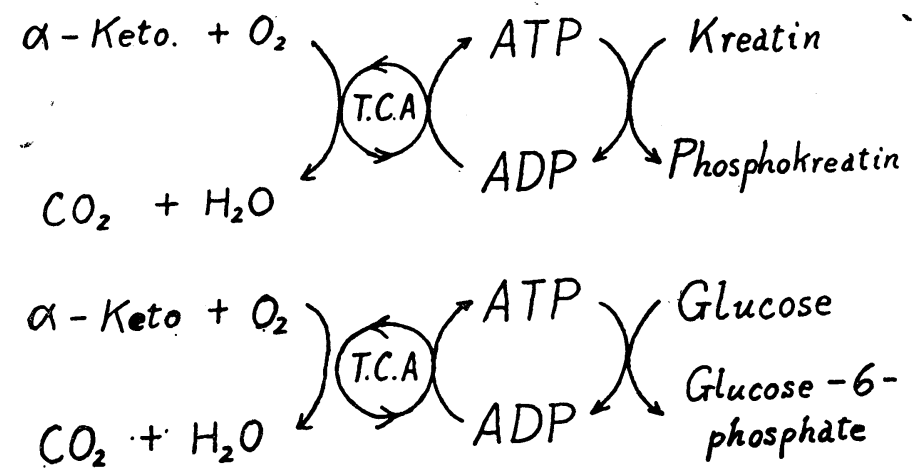

* Diphospho Pyridine Nucleotide 
応生成物がより安定であるへキソキナーゼ法6)を採用した。第 1 図の様に ATPの〜P*をへキりキナーゼ及 びブドウ糖の共存の下で，ブドウ糖 6 燐酸に移行させる方法である。基質は予備実験と同様の $\boldsymbol{\alpha}$-ケトグル夕 ル酸を用いた。処方は第 3 表の通りである。チトクロームGは Nutritional Biochemical Corp. 製品, へキン キナーゼは同社製結晶及び一部 Meyerhof 氏法7)により日東食品製イーストより自製の粗結晶を用いた。 白 鼠は予備実験と同様の条件で，11匹をパロチン群 6 匹，対照群 5 匹に分け，その肝臟の $33 \%$ ホモジェート を醉素液として実験に用いた。 ワールブルグフラスコは 1 つの試料について 4 コづつ用い，気相は空気，摄 氏 35 度で 5 分間空振りの後, 2 コは側室の $87.5 \%(\mathrm{~W} / \mathrm{V}) * *$ の 3 塩化醋酸を混じて直ちに反応を止好無機燐 測定の対照とし, 残りの 2 コは 5 分毎に10分間酸素吸収を測定後, 同様に反応を止めて無機燐の減少を計測

\section{第 3 表}

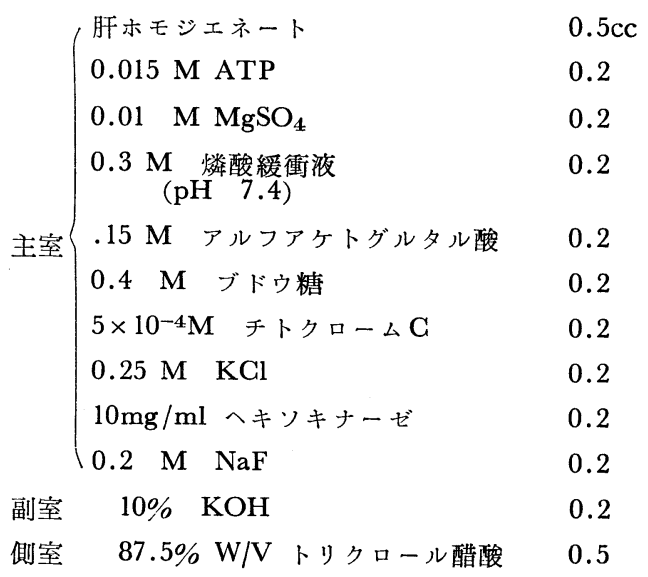

第 4 表

\begin{tabular}{|c|c|c|c|}
\hline & 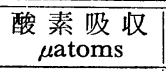 & $\begin{array}{c}\text { 無機燐減少 } \\
\mu \text { moles }\end{array}$ & $\mathrm{P} / \mathrm{O}$ \\
\hline $\begin{array}{c}\text { パロチン群 } \\
\text { No. } 60\end{array}$ & 10.6 & 17.8 & 1.69 \\
\hline No. 61 & 7.3 & 10.6 & 1.46 \\
\hline No. 63 & 7.0 & 10.0 & 1.44 \\
\hline No. 70 & 8.2 & 13.8 & 1.68 \\
\hline No. 78 & 7.5 & 14.3 & 1.91 \\
\hline No. 81 & 5.3 & 10.4 & 1.95 \\
\hline 平 均 & 7.65 & 12.8 & 1.68 \\
\hline $\begin{array}{c}\text { 対 照 } \text { 群 } \\
\text { No. } 76\end{array}$ & 6.9 & 5.9 & 0.85 \\
\hline No. 72 & 8.5 & 9.4 & 1.16 \\
\hline No. $7_{L}$ & 7.2 & 9.5 & 1.32 \\
\hline No. 80 & 6.5 & 7.7 & 1.18 \\
\hline No. 79 & 3.9 & 4.2 & 1.08 \\
\hline 平均 & 6.60 & 7.3 & 1.12 \\
\hline
\end{tabular}

した。

結果は第 4 表の如 $<$, パロチン群 $\mathrm{P} / \mathrm{O}$ 比 平均值 1.68 , 対照群平均值 1.12 と, パロチン 注射群は対照群に比し, 個々の値も平均值も 著明に多く，推計学を用いる迄もない。酸素 吸収, 無機燐減少值か，予備実験比比し多いの は，反応温度が異なる為と，測定法の差によ るものであり，P/O 比が予備実験に比し高 いのは, クレアチン燐酸よりもブドウ糖 6 燐 酸がより安定であり, 反応進行がより円滑と なる為であろう。予備実験で予想した如く， 本実験に於いても，パロチン注射が白鼠肝 藏に於いて ATP 生産を堌強する結果を得 た.

考察

生体内で行われる種々の仕事，殊に合成反 応の関与する仕事に要するエネルギーは， ATP 等の高エネルギー燐酸結合によつて供 給されると云う考元が，今日生化学の分野に 於いては最も支配的である。しかもその ATP の供給源は, 糖分解, 特に TCA 回路に於い て一分子の焦性ブドウ酸が分解する際に15 16個の ATP が生産されることによる。 かく して生じた ATP が生体内代謝過程に於いて 占める重要な役割については，前述の如く膨 大な交献が生化学方面にあるのでてつでは省 略するが，近年 ATP を薬郕として投与した 場合，之が生体に極めて広範囲影に響を与え る事が注目されて来ている。即ち1929年 Drury 及び Szent-Györgyi が ATP の循環系に対 する効果を報告した事に始まり Bennett 及び

* 高エネルギー燐酸結合

**Weight/Volume 
Drury $^{8)}$, Somner ${ }^{9)}$, Herbrand ${ }^{1)}$, Köbcke ${ }^{11)}$, Dubois-Ferriere ${ }^{12)}$ 等が何れもアデニル酸, AMP, ADP, ATP 等を心疾患を始多くの疾患伇与して，血管拡張作用，循環血液量の増加を認めた他，狭心症心筋梗塞， 高血圧等に臨床的に有効であると報じている. 1953年 Winbury 等は犬の冠循環血量をロタメーターで測定

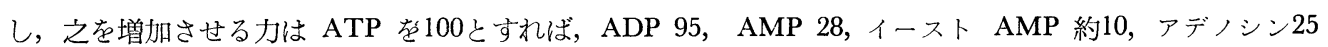
の割合であつて，アデニン及びクレアチン燐酸には冠循環血量増加作用を認めなかつた

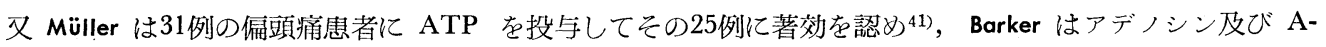
MP が間歇性跛行症に著効がある11) と報じている.

一方パロチンについては，金子は間歇性跛行㱏の症状を改善し，心臓性喘息，心筋梗塞にも効果がある15) と報告している。参木 ${ }^{16)}$ 及び馬詰 ${ }^{2}$ はパロチン使用が網膜中心動脈の最低血圧を降下させると報告し，高岡 はレイノ一氏病にパロチンの効果を想》，更に心電図上ST の著明な低下を伴つた瘗心症が，パロチン使用 により心電図の正常化と症状の改善を来した例を報告している ${ }^{17)}$. 金子山田等は高血圧及び脳出血後遺症に

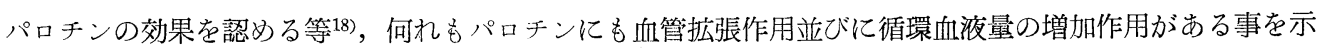
唆している.

1) ウマチに対しては Carlström 及び Lövgren は ATPを投与するとその症状及び血沈值が改善されると 報告 ${ }^{19)}$ ，Dubois-Ferriére 他の古典的療法が然効であつた患者に ATP 注射を行い，その60〜80\%に運動機能 の回復と症状の改善を锠めている12). 彼は ATP がリウマチに効く理由は単なる血管拡張作用のみならず， 燐酸化を強める事によつて生物学的触媒 Catalyseurs Biologiques の欠乏を改善する事にあるのではないか

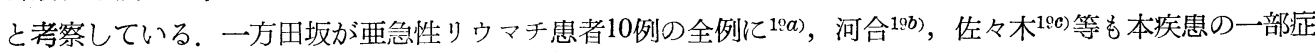
状にパロチンの効果を認めているが，乙の事もATPのリウマチ疾患に対する効果と考え合せて興味深いと 思われる。

Kleinsorge 及び Schuchardt23)，Nissen21) はATP が糖尿病に対して有効であるのは,ヘキソキナーゼ活性 を刺㦸して肝グリコーゲンを増加させる為であろうと報告し, Kleinsorge 等は健康人36例に ATP を投与し た場合にも，その32例に血糖降下を認めている．為田はパロチンも正常犬の血糖を低下させる22)と報告して いる.

Feldman はビタミンE灭による家兔の筋萎縮症の進行を ATP が阻止した ${ }^{23)}$ と報告し，Lehoczky は多発 性硬化症患者55例にビタミン $B_{1}$ と ATP を同時に投与した所，その31例に軽快を認め24), Dubois-Ferriereも その歩行失調症, 筋緊張昂進等に好結果を得ているが，パロチンに於いても高岡等はクレアチンの尿中排泄 が抑制され，クレアチン尿を有する筋疾患にパロチンが有効な事を認めている。ビタミン $\mathrm{B}_{\mathbf{1}}$, 代謝に於いて パロチン注射がそのエステル型を増加させる事は前述の通りである1). 臨床的に ATP とパロチンの効果が 以上の如く類似している点は極めて興味満い.

次に他のホルモンの $\mathrm{P} / \mathrm{O}$ 比に及ぼす影響を文献的に見ると，その多くは in vitro の影響が研究されて いる為, 今回私が行つた in vivo の実験成績とを直ち比較検討する事は出来ないが，簡単に列挙すると次 の如くである。

1）甲状腺ホルモン Maley 及び Lardy によれば，甲状腺ホルモン及びサイロキシンを in vitro に加え た白鼠の肝㵴では，P/O 比が対照よりも低下している25). Lardy 及び Maley によるとサイロキシンは in

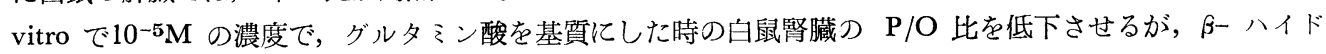
ロキシブチレート及びカプリル酸を基質にした時には，P/O 比を低下させない25)と報告している.

2) インシュリン Smith 等によれば,インシュリンは in vitro でアロキサン糖尿病白鼠の肝ホモジェネ

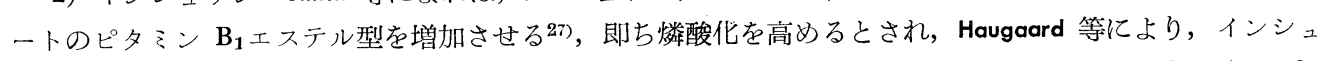
リンはブドウ糖存在の下に於いて，ATP 及びクレアチン燐酸を消費して，燐酸エステルの形成を助ける28) と報告されている. Polis は0.8ccの肝ホモジェネートに0.02 0.2単位のインシュリンを in vitro で加える と, 僅加ではあるが推計学的に有意な $\mathrm{P} / \mathrm{O}$ 比増加が起る為, インシュリンは少く共 TCA サイクルに促進 的に作用する29) と述べている. 
3) コルチゾン 比較的以前より, 臨床応用の際に合計 1 瓦の使用により炭水化物代謝が障害されたとの 報告があり ${ }^{30)}$ ，最近は Cortisone Diabetes が問題にされている。コルチゾンを注射された白鼠の骨格筋の クレアチン橉酸及び ATP の含量には変化がなかつたという報告31ももある. Bacilla はコルチゾンはへキソ キナーゼの SH 基に結合して $\mathrm{P} / \mathrm{O}$ 比を抑制するのであろう32)と述べている.

4) 性ホルモン 蛋白同化作用がある MAD* は臨床的使用の際 AGTH の蛋白分解作用に拮抗するが34) エストロゲン系の化合物は $10^{-4} \mathbf{M}$ の濃度で，in vitro 及び肝切片（Slice）に添加した時にコハク酸酸化酵 素を80\%抑制するといわれている. 又ヂェチルスチルブステロールはマロン酸よりも強い阻害作用を示し， 白鼣肝切片のコハク酸酸化酵素を抑制している ${ }^{3 \overline{5})}$.

5) 成長ホルモン 成長ホルモンは TCA 回路の一員であるコハク酸酸化醳素には, 特異的な働きは証明 されていない35).

即ち現在迄知られている半ルモンについて得られた成績は, 実験条件, 測定対象が異なる為, 各々を直接比 較する事は出来ないが，少く共蛋白合成的に働くといわれているインシュリンでは $\mathrm{P} / \mathrm{O}$ 比が上昇し, 蛋白 分解的に働くとされているサイロキシンには $\mathrm{P} / \mathrm{O}$ 比抑制的な作用がある事から考えると，パロチンの

第 2 図

$\mathrm{RNH}_{2}+\mathrm{ATP} \rightarrow \mathrm{R} \cdot \mathrm{NH} \cdot \mathrm{ADP}+\mathrm{H}_{3} \mathrm{PO}_{4}$

$\mathrm{R}^{1} \mathrm{COOH}+\mathrm{ATP} \rightarrow \mathrm{R}_{1} \cdot \mathrm{CO} \cdot \mathrm{ADP}+\mathrm{H}_{3} \mathrm{PO}_{4}$

$\mathrm{R} \cdot \mathrm{NH} \cdot \mathrm{ADP}+\mathrm{R}_{1} \mathrm{COOH} \rightarrow \mathrm{RNHCOR}_{1}+\mathrm{ADP}$

$\mathrm{R}^{1} \mathrm{COADP}+\mathrm{RNH} \rightarrow \mathrm{R}_{1} \mathrm{CONHR}+\mathrm{ADP}$

* 三回

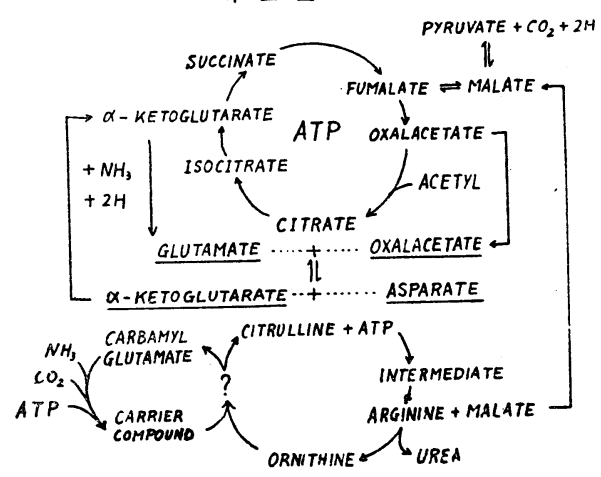

$\mathrm{P} / \mathrm{O}$ 比上昇作用の意義が明確になると思われ

る.さらに ATP が第 2 図の如く, 広くペプチ ド基の結合に用いられる37ばかりでなく，自由 アミノ基加らのペプチド合成の唯一の場合であ るグルタチオンの合成にも必要であり ${ }^{38)}$, 前述 のトランスアミナーゼが第 3 図の如く酸化的燐 酸化之密接な関係にある ${ }^{39}$ 事を考えれば，パロ チン注射による $\mathrm{P} / \mathrm{O}$ 比の上昇即ち ATP の増 加は之等ペプチドの合成にも好影響を示す事に なる。乙の事はパロチンがトランスアうナーゼ 活性や， $\mathrm{G}^{14}$-グリシンの肝蛋白への取入れを増 加させる事と良く一致し, 石川が指摘した如く パロチンが蛋白合成と密接な関係を有する事を 肯定させるものである。 Cantarow が ATP は G14-アラニンのミトコンドリア蛋白への取入れ を增す40) と報告している如く, 蛋白合成とATP とは不可分の関係にあり, パロチンによる蛋白 合成作用 ${ }^{33)}$ も ATP の增産なくしては考えられ ない．臨床的に水溶性ビタミンを単独に使用して無効な場合，パロチンの併用が望ましい事もATP の関係 から理解されるが，乙の事は教室入江等の Behcet 症候群に対するパロチンの使用融によつて，立証されて いる. 最近佐瀬 ${ }^{(4)}$ は雄性ハムスターの肝ミトコンドリアを用いてパロチンが酸化的燐酸化を促進すると報告 している.

\section{結 論}

白鼠にパロチンを注射し 6 時間後に屠殺した際の肝ホモジェネートの $\mathrm{P} / \mathrm{O}$ 比は，対照群に比し増加する 事を認めたので, パロチンの注射が肝の ATP を増加させるものと考える.

パロチンの作用機序とその臨床的応用について ATP の生理的作用の面汃ら若干の考察を加えた.

(予備実験の成績の一部は第27回日本生化学会総会に於て報告した)

\footnotetext{
* Methylandrostenediol
} 
㨨筆するに当り。終始御指導, 御鞭達を戴いた恩師冲中教授, 高岡講師, 本実験の遂行に当り御指導, 御 援助を頂いた教室山田博士，二宮博士，石川学士，本学農学部農芸化学教室中村助教授に深謝する.

\section{文献}

1) 高岡善人, 宇尾野公義 : 診療 7 巻 9 号, 65頁, 昭29年; Klin. Wschr. 33 (15) : 156, 1955. med. Scand. $115: 568,1943$.

34) Homburger, F. et al. : J. Glin. Endocrin. \& Metab. 13 : 704, 1953.

35) Meyer, B.K. \& Mcshan,

W.H. : Recent Progr. in Hormone Res. 5 : 465, 1950.

36) Gaebler, O.H., Mathies, J.C. \& Palm, L.

: Endocrinology 45 : 267, 1949.

37) Cohen, P.P. : The Enzyme, Vol. 1. Part2 1040P, 1951.

Block, K., Snoke, J.E. \& Yanari, S. : Phosphorous Metabolism 2 : 82, 1952.

39) Rattner, S. : Ibid.

$1: 601,1952$

40) Cantarow, A. et al. : Cancer Research $14: 115,1954$.

41) Müller,

G.M. : Münch. med. Wschr. $1953: 273$.

42）馬詰嘉吉, 文部省科学研究報告, 288頁, 昭和28年,

43) 入江実, 他：骖断と治療 44 巻 8 号 842 頁, 昭 31 .

44）佐瀬民雄 : 倕液腺ホルモンシンポジウム

（昭和31年11月14日）で口述 